\title{
HOW DOES TAX AVOIDANCE AFFECT FIRM VALUE? (LESSONS FROM SOE AND INDONESIAN PRIVATE COMPANIES)
}

\author{
Maulida Aulia Rezki ${ }^{*}$, , Noer Azam Achsani ${ }^{*}$, and Hendro Sasongko**) \\ *) School of Business, IPB University \\ Jl. Raya Pajajaran, Bogor 16151, Indonesia \\ **) Faculty of Economics, Universitas Pakuan \\ Jl. Pakuan, Bogor 16129, Indonesia
}

\begin{abstract}
Taxes are the main source of state revenue and become an important factor for the running of government and development of the country with the largest contribution coming from corporate income tax. Different objectives of business ownership result in different tax management. This study analyzes the characteristics of tax avoidance, determinants and influences on firm value in state-owned and private companies. This study uses secondary data sources in the form of quarterly company financial statements, company stock price reports, and other related data. Descriptive and panel data analysis were used to examine the sample in this study which includes non-financial companies that are continuously profitable and listed in the LQ45 index for the period February 2014 to July 2019. The results of the study explain that private companies are more dominant in tax avoidance conduct compared to State-Owned Enterprises (SOEs). The determinants that influence the tax avoidance of SOEs are ROA and firm size, whereas in private companies there are no determinants that have a significant effect. There is significant negative impact in State-owned companies from tax avoidance on the firm value, while private company does not have a significant effect.
\end{abstract}

Keywords: effective tax rates, firm value, SOE, Private, tax avoidance

\begin{abstract}
Abstrak: Pajak merupakan sumber pendapatan utama negara dan menjadi faktor penting bagi roda pemerintahan dan pembangunan negara dengan kontribusi terbesar berasal dari pajak penghasilan perusahaan. Perbedaan tujuan dari kepemilikan usaha mengakibatkan manajemen pajak yang berbeda. Penelitian ini bertujuan menganalisis karakteristik penghindaran pajak, determinan faktor, dan dampak terhadap nilai perusahaan pada perusahaan BUMN dan swasta. Penelitian ini menggunakan sumber data sekunder dari laporan keuangan, harga saham, dan data lainnya. Analisis deskriptif dan data panel digunakan untuk menjelaskan sampel penelitian yang mencakup perusahaan non-keuangan yang terus menguntungkan dan terdaftar dalam indeks LQ45 untuk periode Februari 2014 hingga Juli 2019. Hasil penelitian menjelaskan bahwa perusahaan swasta lebih dominan melakukan penghindaran pajak dibandingkan perusahaan BUMN. Determinan faktor yang memengaruhi penghindaran pajak perusahaan BUMN yaitu ROA dan ukuran usaha, sedangkan pada perusahaan swasta tidak ada determinan yang berpengaruh signifikan. Pada perusahaan BUMN terdapat pengaruh negatif yang signifikan dari penghindaran pajak terhadap nilai perusahaan, sedangkan swasta tidak memiliki pengaruh yang signifikan.
\end{abstract}

Kata kunci: effective tax rate, nilai perusahaan, BUMN, perusahaan swasta, penghindaran pajak,

${ }^{1}$ Corresponding author:

Email: maulida.mar@gmail.com 


\section{INTRODUCTION}

Indonesia is a developing country that requires a large budget for growth in all sectors. This encourages countries to increase sources of income. The main source of state revenue which is also an important factor in the running of government and development, is derived from taxes with the composition of state revenues reaching 82.5 percent (Ministry of Finance, 2019). The largest tax contribution in Indonesia comes from companies as taxpayers through income tax. Income tax dominates to reach more than half of total tax revenue each year (DGT, 2018).

Taxes, is a source of state welfare, however on the company perspective it becomes a burden for business entities (Chen et al. 2010). The company is trying to pay the lowest possible tax because it reduces income or net profit, while the government expects the highest tax possible in order to finance the development plan. This difference in perspective causes taxpayers to try to reduce tax payments, both legally and illegally.

One way to reduce tax payments is tax avoidance. The company makes consider tax as a problem because it can reduce company revenue, hence tax policies and arrangements are carried out through tax avoidance without ignoring the tax payment rules. Tax avoidance is carried out by companies with the aim of reducing the tax burden through various alternatives that are still acceptable to the tax authorities (Desai and Dharmapala, 2009). Good tax management is necessary in implementing tax avoidance so as not to get caught up in tax evasion.

Tax avoidance that aims to reduce costs in order to prosper the owner, has an influence on the shares value. This can be seen from the movement of the shares value compared to the average effective tax rate (ETR) or the amount of tax payments to the company's revenue in 2014-2018. When ETR changes, the value of the shares also changes. (IDX, 2019). This shows that tax avoidance not only affects income, but also affects the shares value which will affect the firm value.

The impact of tax avoidance has diverse effects on firm value. According to previous research by Desai and Dharmapala (2009), tax avoidance tends to add value to well-managed companies but this influence does not apply to companies with poor governance. However, the results from other studies are not consistent. Hanlon and Slemrod (2010) examined the market reaction to the application of the tax shield. In general, stock prices declined at the time of the announcement, but with a small type of industry variant and only significant in retail industries.

Companies have different goals based on their ownership which is divided into SOE and private companies. SOEs are dominated by the government and aim to help the government in managing the interests of the people. The aim of SOE is not only to prosper the interests of the owners as companies in general, but also to be responsible for the welfare of the people and the development of the country's economy. This difference results in different tax management for the company to fulfill its objectives. According to Chen et al. (2010), government-controlled companies have a political goal to protect state revenue so as to encourage companies to avoid pursuing effective tax planning.

Company ownership determines stances in making corporate tax payments according to Riyadi (2018). Companies with a government ownership structure have a significant positive effect on the level of tax avoidance, but the Initial Public Offering (IPO) for government companies makes the tax avoidance level even lower. However, the results of Rumiyati's research (2016) stated that the political relations that companies have do not influence a significant relationship to tax avoidance in manufacturing companies on the IDX. According to Rosaria(2017), research on state ownership companies has a significant positive relationship to ETR or negative on tax avoidance. This is because the government encourages and contributes also in collecting taxes from companies for the country so that the company ownership also has that role. Decision determinant that affect tax avoidance are seen more in the positive influence between the characteristics of company executives on the occurrence of tax avoidance (Budiman, 2012). According to Hutama (2007), the factors that are assumed to influence someone doing tax avoidance are related to moral principles, the higher the morale, the lower the tendency to avoid taxes.

Tax for firm is a burden that will reduce net profit, hence the company always wants minimum tax payment (Kurniasih and Sari, 2013). Tax espense are burdensome for companies and their owners, resulting an effort for tax avoidance (Chen, 2010). Companies take advantage of unclear regulations in the context of tax avoidance to obtain favorable tax outcomes (Dyreng et al. 2008). Tax 
avoidance is often associated as a series of tax planning strategies. According to Hanlon and Heitzman (2010), tax avoidance is an explicit tax rate reduction that represents a series of tax planning strategies that begin with tax management, tax planning, tax aggressive, tax evasion, and tax sheltering.

Tax avoidance influenced by company internal factors. Research on the factors influencing tax avoidance has been carried out numerous times, such as research by Atwood et al. (2012); Deak (2009). Likewise, in Indonesia, there have been many studies on tax avoidance such as Lestari et al. (2014). Tax avoidance is the ability of a company to pay cash-effective tax rate on profit before tax on the company (Dyreng et al. 2008). The company's internal factors are leverage, profitability, firm size, institutional ownership (Vidiyanna, 2017; Evangelos et al. 2018). The results have similarities in leverage and institutional ownership which have no effect on tax avoidance, in contrast, the effect of profitability is significantly positive on tax avoidance (Vidiyanna, 2017) and significant negative (Evangelos, 2018; Nguyen and Phan, 2017).

Trade-off theory explains that companies have the option to be in debt, in order to get interest benefits to reduce tax payments. Companies with greater debt will result in lower tax payments and will yield high tax avoidance. Debt made will affect leverage, capital intensity, profitability, and firm size because it will directly affect the company's assets. Factors that influence tax avoidance according to the results of previous studies have a similar form calculated by the effective tax rate as a description of tax avoidance. Research by Andreas and Enny (2017); Evangelos et al. (2018); and Vidiyanna and Putra (2017) provided an explanation that the factors influencing tax avoidance is profitability as measured by ROA, leverage, capital intensity, and firm size. These factors have a significant effect on tax avoidance. Research by Maharani and Suardana (2014) shows that profitability has a negative effect on tax avoidance. Similarly, research conducted by Kurniasih and Sari (2013) states that profitability has a negative effect on tax avoidance. According to Irianto et al. (2017), leverage has a positive relation with tax avoidance and firm size has a negative effect. While capital intensity has a positive but not significant effect.
Tax avoidance is carried out to increase the firm value so that management looks good for the shareholders. Decision-making management should pay attention to the benefits and costs to be obtained by the company. In the decision-making process, the benefits to be received by the company should be greater than the costs incurred. However, the impact of tax avoidance on firm value according to many studies has different results. Research by Desai and Dharmapala (2009) there is a positive influence between tax avoidance on firm value. Meanwhile, Apsari and Setiawan (2018); Appolos et al. (2016) results in the negative influence of tax avoidance on firm value according to research. Tax avoidance is proxied by an effective cash tax rate (cash ETR).

According to the explanation above, the literatures and the results of previous studies, the following hypotheses can be concluded: 1) Factors that have an influence on tax avoidance on companies listed on the IDX, among others, namely a. Firm size, leverage, and capital intensity have a positive effect on tax avoidance; b. Profitability has a negative effect on tax avoidance. 2) Tax avoidance has a positive influence on the firm value on companies listed on the IDX.

Based on the different goals based on their ownership, it is necessary to conduct research to analyze the characteristics of development, the factors that influence, and the impact of tax avoidance on the firm value on state-owned and private companies in Indonesia. This research will provide benefits for companies in the form of knowledge for management, referrals for investors in investment decision making, and decision making in government taxation regulations.

\section{METHODS}

This study uses secondary data sources in the form of quarterly company financial statements, company stock price reports, and other related data through a descriptive approach and panel data regression model. Descriptive analysis is used to describe the data under study and panel data regression is used to analyze the effect of each variable.

The sample used in this study is companies in the nonfinancial sector which always listed on the IDX LQ45 index in the February 2014 to July 2019 period and always experience profit conditions. The LQ45 index 
is one of the stock index indicators on the IDX that can be used as a reference material to assess company performance. Based on these criteria, 24 companies were sampled consisting of 9 state-owned companies and 15 private companies. Variables in this study consisted of firm size, leverage, return on asset, capital intensity, effective tax rate (tax avoidance), and firm value. The firm size is shown through total assets in rupiah, because this measure is considered to have a better level of stability compared to other proxies and tends to be related between periods.

The firm size is shown through total assets in rupiah, because this measure is considered to have a better level of stability compared to other proxies and tends to be continuous between periods (Kurniasih and Sari, 2013). Company size is measured using natural logarithm of total assets. The formula for calculating company size is:

$$
\text { Size }=\operatorname{Ln}(\text { Total Asset })
$$

Leverage is a ratio to measure the ability of both longterm and short-term debt to finance company assets (Kurniasih and Sari, 2013). Leverage can be measured using the ratio of total debt to equity ratio. The formulas for calculating leverage are:

Debt to Equity Ratio $=($ Total Liability $) /($ Total Equity $)$

ROA is the ratio between net income and total assets at the end of the period that is used as an indicator of a company's ability to generate net income. ROA in percentage, calculated by dividing net profit after tax by total assets (Chen et al. 2010). The formula for calculating return on assets, namely:

\section{$\mathrm{ROA}=($ Net Income After Tax/Total Assets) $\mathrm{x}$ 100\%}

Capital Intensity gives an idea of how much capital is needed to generate income. Investments made by the company must always consider every opportunity to fight over the market. Indicators of the company's future prospects can be seen from the side of capital intensity which illustrates the ratio between fixed assets and total assets. The formula for calculating capital intensity is:

Capint $=($ Total Fixed Assets $) /($ Total assets $)$
Tax avoidance is measured using the effective tax rate (ETR). Frank et al. (2009) used ETR in his research because it was considered to reflect a fixed difference between the calculation of book income and fiscal profit. ETR value is obtained by dividing the total tax burden by profit before tax. ETR is calculated using the ratio of total income tax expense to pre-tax income. Income tax expense is the sum of current tax expense and deferred tax expense. Pre-tax income is net income before deducting income tax. The smaller the ETR value means the greater the tax avoidance by the company and vice versa the greater the ETR value the smaller the tax avoidance. ETR values range more than 0 and less than 1 . The formula for calculating tax avoidance, namely:

$$
\mathrm{ETR}=(\text { Tax Expense }) /(\text { Pretax Income })
$$

Firm value is the investor's perception of the company, which is often associated with stock prices. To be able to create value for the company, financial managers must try to make the right investment, funding, dividend, and net working capital investment decisions (Salvatore, 2012). According to Sukamulja (2004), Tobin's Q ratio is considered as the ratio that is able to provide the best information because Tobin's Q ratio includes all elements of the company's debt and stock capital, not only shares and the company's equity, but also includes all of the company's assets.

Tobin $=($ MVE + Book Value of Liabilities $) /($ Total Aset $)$

Descriptive analysis uses a description of a data that is seen from the average, maximum value, minimum value, and standard deviation. For panel data regression to determine the factors that influence tax avoidance use the economic model as : $\mathrm{ETR}=\mathrm{F}(\mathrm{ROA}, \mathrm{LEV}$, CAPINT, SIZE). Then to measure the impact of tax avoidance on firm value, the model is added back to:

$$
\mathrm{Q}=\mathrm{F}(\mathrm{ETR})
$$

Regression 1:

$$
\begin{aligned}
\mathrm{ETR}_{\mathrm{t}}= & \alpha_{\mathrm{t}}+\sum_{i=1}^{p} Y_{j} R O A_{t-i}+\sum_{i=1}^{p} \partial_{j} L E V_{t-i}+ \\
& \sum_{i=1}^{p} \theta_{j} \text { CAPINT }_{t-i}+\sum_{i=1}^{p} \varepsilon_{j} \operatorname{SIZE}_{t-i}+\mathrm{zt}
\end{aligned}
$$


Variable: ETR (Effective tax rate); ROA (Return on asset); LEV (Leverage); Capint (Capital intensity); Size (Firm size).

Regression 2:

$$
\mathrm{Qt}=\alpha_{\mathrm{t}}+\sum_{i=1}^{p} Y_{j} E T R_{t-i}+\varepsilon \mathrm{t}
$$

Variable: Q (firm value); ETR (Effective tax rate)

\section{RESULTS}

\section{Descriptive analysis}

The study analyzed 24 companies that are always listed on the Indonesia Stock Exchange LQ45 index (IDX) during the period 2014 to 2019. The LQ45 index is a stock index with high liquidity, which is selected through several selection criteria. This index calculation is based on the market value of 45 selected shares selected once every 6 months.

SOE is a business entity which ownership is dominated by government and aims to assist the government in managing the interests of the people. The aim of SOE is not only to prosper the interests of its shareholders just like companies in general, but also to be responsible for the welfare of the people and the development of the Indonesian economy. While a private company is a business entity in which the capital comes from the private sector, be it domestic or foreign private parties. The main purpose of a private company is to improve the welfare of its owner so as to encourage the company to get the maximum profit.

The SOEs analyzed have an average debt to equity ratio (DER) of 2.96, which means they have a much larger amount of debt compared to their equity. While the profitability of SOEs as seen from return on assets (ROA) has an average of 4.01 percent with the use of fixed assets at 19 percent of the total assets owned. The value of SOEs also has an average of 1.42. Meanwhile, private companies have an average amount of debt equivalent to corporate equity of 1.05 (DER) and ROA value is greater than that of SOEs, which is 6.81 percent with an average fixed asset use of 26 percent of the total assets. While the firm value of private companies is far greater than that of SOEs, reaching a value of 3.20 (Table 1).

\section{Characteristics of Tax Avoidance}

Tax avoidance in this study is measured using the company's effective tax rate (ETR) which is considered to reflect the fixed difference between the calculation of book income and fiscal profit. The ETR value ranges from 0 to 1 and the smaller the ETR value means that the tax avoidance by the company is getting bigger and vice versa. Average ETR value of SOE and private companies are as follows.

The average tax avoidance seen from the types of SOE and private companies results in a more dominant private company in doing tax avoidance compared to SOEs. The companies included in SOE have an average tax avoidance value of 0.29 or 29 percent while private companies have an average tax avoidance value of 0.23 or 23 percent (Table 2). This happens because SOEs can be more directly monitored by the government therefore more transparent tax payments detection. This is consistent with research using all companies except financial institutions on the Shanghai and Shenzhen Stock Exchanges between 2003 and 2009 by Chen et al. (2013) and found that managers of governmentcontrolled companies have political objectives to protect government revenues so they encourage companies to avoid pursuing aggressive tax planning. Their evidence means that government-controlled companies pursue less aggressive tax strategies compared to nongovernment controlled companies.

\section{Determinants of factors that affect tax avoidance}

The following steps are carried out to answer, namely to test the determinants of factors that affect tax avoidance in LQ45 companies in the period 2014 to 2019 quarter 2. This method using panel data regression and EViews 9. The regression results from the determinants of factors that affect tax avoidance are as Table 3 .

Table 1. Conditions of SOE and private companies in the 2014-2019 period

\begin{tabular}{lcccccc}
\hline Ownership & ETR & SIZE & DER & ROA $(\%)$ & CAPINT & TOBIN'S Q \\
\hline SOE & 0.29 & 32 & 2.96 & 4.01 & 0.19 & 1.42 \\
Private & 0.23 & 31 & 1.05 & 6.81 & 0.26 & 3.20 \\
\hline
\end{tabular}

Source : Company financial statements (2014-2019) 
Table 2. Average ETR value of SOE and private companies in the 2014-2019 period

\begin{tabular}{cc}
\hline Category & ETR \\
\hline SOE & 0.290743 \\
Private & 0.231893 \\
\hline
\end{tabular}

Source : Company financial statements (2014-2019)

The results of the analysis in Table 3 show that from the independent variables studied in SOE companies, there are 2 variables that have a significant effect and 2 variables that are not significant. Variables that have a significant influence are shown by probability values below 0.05 , namely ROA and firm size and both have a significant negative effect on ETR or positive on tax avoidance. While capital intensity and debt to equity ratio have no significant effect on the value of ETR of the company.

The results of the analysis in Table 4 show that from the independent variables studied in private companies. There are no variables that have a significant effect in private companies. This results indicated by all probability values above 0.05 . The summary results of determinants factor that affect tax avoidance in Table 5.

\section{Effect of Capital Intensity on Tax Avoidance}

Capital intensity is the ratio between fixed assets and total assets which is used to find out how much the company's investment is in the form of fixed assets (Imelia, 2015). The company's fixed assets allow the company to withhold taxes due to depreciation of fixed assets annually (Rodiguez and Arias, 2012). This shows that companies that decide to invest in fixed assets are allowed to calculate depreciation which can be used as a deduction for taxable income and as an effort for tax management.
The results of this study do not provide results in accordance with the theory which states that fixed assets can cut taxes due to their depression (Rodiguez and Arias, 2012), but these results are in line with research conducted by Richardson and Lanis (2007) which shows that capital intensity has no significant effect to ETR. The condition of companies that invest in fixed assets that have no effect on tax avoidance is due to the company makes investments to facilitate business operations. This is consistent with the financial statement data which in general the company has fixed assets that are used as business support. therefore more companies aim to increase fixed assets to increase company revenue from sales. In addition, the type of business studied has a business nature that generally requires tools hence assets remain as a necessity rather than merely as a deduction from payment of taxes due to depreciation. In the product producing industry, fixed asset is very influential on production capacity. Thus, the greater the fixed assets owned by the company, the greater its production capacity. This will result in increased sales due to more production. The increase in sales means an increase in income which will have implications for the increased tax burden that must be paid by the company.

\section{The Effect of Debt to Equity Ratio (DER) on Tax Avoidance}

Debt to equity ratio (DER) is a leverage ratio that refers to the use of assets or funds to increase benefits or company profits. When the ratio is high, it means that the company uses large debt to increase the profitability of the company, but on the other hand, large debt carries a great risk which is likely to result in a decrease in profits. Reduced profits cause a decrease in taxes paid so the company's effective tax rate falls.

Table 3. The results of determinants factor that affect tax avoidance on SOE Company

\begin{tabular}{lccccc}
\hline & Variable & Coefficient & Std. Error & t-Statistic & Prob. \\
\hline Constant & C & 2.613 & 0.545 & 4.796 & 0.000 \\
Capital Intensity & CAPINT & -0.060 & 0.117 & -0.508 & 0.612 \\
Debt to Equity Ratio & DER & 0.003 & 0.009 & 0.315 & 0.753 \\
Return on Assets & ROA & -0.237 & 0.066 & -3.623 & 0.000 \\
Size & SIZE & -0.085 & 0.019 & -4.491 & 0.000 \\
The previousperiod effective tax rate & ETR(-1) & 0.293 & 0.070 & 4.184 & 0.000 \\
\hline R-squared & 0.642328 & & & & \\
F-statistic & 24.17506 & & & & \\
Prob (F-statistic) & 0 & & & & \\
\hline
\end{tabular}


Table 4. The results of determinants factor that affect tax avoidance on private company

\begin{tabular}{lccccc}
\hline & Variable & Coefficient & Std. Error & t-Statistic & Prob. \\
\hline Constant & C & 0.618 & 0.462 & 1.337 & 0.182 \\
Capital Intensity & CAPINT & 0.014 & 0.028 & 0.490 & 0.624 \\
Debt to Equity Ratio & DER & 0.004 & 0.010 & 0.394 & 0.694 \\
Return on Assets & ROA & 0.008 & 0.046 & 0.184 & 0.855 \\
Size & SIZE & -0.015 & 0.015 & -1.001 & 0.317 \\
The previous period effective tax rate & ETR(-1) & 0.297 & 0.056 & 5.328 & 0.000 \\
\hline R-squared & 0.859547 & & & & \\
F-statistic & 95.0186 & & & & \\
Prob (F-statistic) & 0 & & & & \\
\hline
\end{tabular}

Table 5. The summary results of determinants factor that affect tax avoidance

\begin{tabular}{lccc}
\hline \multirow{2}{*}{ Variable } & \multicolumn{2}{c}{ Tax Avoidance Relations } & \multirow{2}{*}{ Hypothesis } \\
\cline { 2 - 3 } & SOE & Private & \\
\hline Capint & Positive not significant & Negative not significant & Positive \\
DER & Negative not significant & Negative not significant & Positive \\
ROA & Positive significant & Negative not significant & Negative \\
Size & Positive significant & Positive not significant & Positive \\
\hline
\end{tabular}

The negative relationship between DER and tax avoidance in companies is in accordance with the research of Irianto et al. (2017). This is due to many companies use debt not only to finance the company's operations, but also for investment purposes that generate income outside the company's business such as owning stock assets. In addition, companies also have large liabilities from down payment payments where the debt has no interest which will reduce tax payments. Construction and real estate and infrastructure companies also have concessions on loan interest rates due to the president's policy in carrying out state development. The companies included in LQ45 are companies that are classified as large companies and generally have a variety of business diversifications. The company has access to debt loans with its own part of the company so that it gets a low-interest loan. However, the effect of DER is on significant to tax avoidance, possibly because in some companies there are differences in conditions where when DER rises or falls does not affect the value of ETR of the company and as shown in the Figure 1, companies that have high or low DER generally still have an average ETR that is not far proportional between sectors.

\section{The Effect of Return on Assets (ROA) on Tax Avoidance}

Profitability measured by return on assets (ROA) in this study is an indicator that reflects the company's financial performance, the higher the value of ROA, the better the company's performance. The level of income tends to be directly proportional to the tax paid. Companies that have high levels of profit tend to have high taxes.

The results showed the different effect of ROA on tax avoidance in state-owned and private companies. SOEs have a significant positive effect between ROA and tax avoidance while private companies do not have a significant effect.In state-owned companies return on assets which has a positive influence on tax avoidance is in accordance with previous research (Lannis and Richardson, 2007; Kurniasih and Sari, 2013). The higher the profitability of the company, the higher the company's net profit generated. Agency theory provides an understanding that this activity will spur agents to increase company profits. When the profits are increased, the amount of income tax will increase in accordance with the increase in corporate profits so that the tendency to do tax avoidance by the company will increase. In addition SOEs has a dual purpose besides increasing profits, but also the need for activities to help the country's economic movement. This results in conflicting purpose. When companies aim to increase state revenues by increasing tax payments, this results in the possibility of shifting funds according to interests.

ROA in private companies does not have a significant effect on tax avoidance because private companies 
do not have an interest in the welfare of the country. Decisions in determining the profitability of companies do not affect the attitude of tax avoidance because private companies allocate more funds in CSR activities but with the additional purpose of promotion. Taxes are considered not directly affect the company so companies prefer to allocate funds to other activities such as education funding or community assistance.

\section{The Effect of Firm Size on Tax Avoidance}

The firm size is a scale of companies classified large or small through certain ways and one of them by looking at the size of the assets owned. The greater the assets owned by the company it is expected to be able to have a large amount of productivity as well and then it will affect the company's revenue results. According to Rodiguez and Arias (2012) large companies have a greater tendency to do good tax planning and adopt effective accounting practices to reduce corporate ETR.

The results showed differences in the effect of business size on tax avoidance in state-owned and private companies. SOEs have a significant positive effect between business size and tax avoidance while private companies do not have a significant effect. State-owned companies provide results that are in line with research by Richardson and Lanis (2013) which states that large companies have lower effective tax rates because they have sufficient resources to carry out processes according to the company's wishes such as carrying out tax planning and activities to achieve other optimal tax savings. In addition, the greater the company will produce more complex corporate transactions so that the more likely it is to do tax loopholes. This is because the company uses political power in its tax management.

\section{Impact of Tax Avoidance on Firm value}

Further research was conducted to analyze the effect of tax avoidance on the firm value in each of the companies ownership registered in LQ45 in the 2014 to 2019 quarter 2 periods using panel data regression and EViews 9 software. In the regression for this SOE company the research uses the Chow Test and the Hausman Test to find out the right model to use. The results of the two tests show the right model used in this regression is the fixed effect model (FEM). To find out that the results of the regression model are free from classical assumption problems such as heteroscedasticity, multicollinearity, and autocorrelation, then the classical assumption test is carried out on the FEM regression model that has been selected.

3

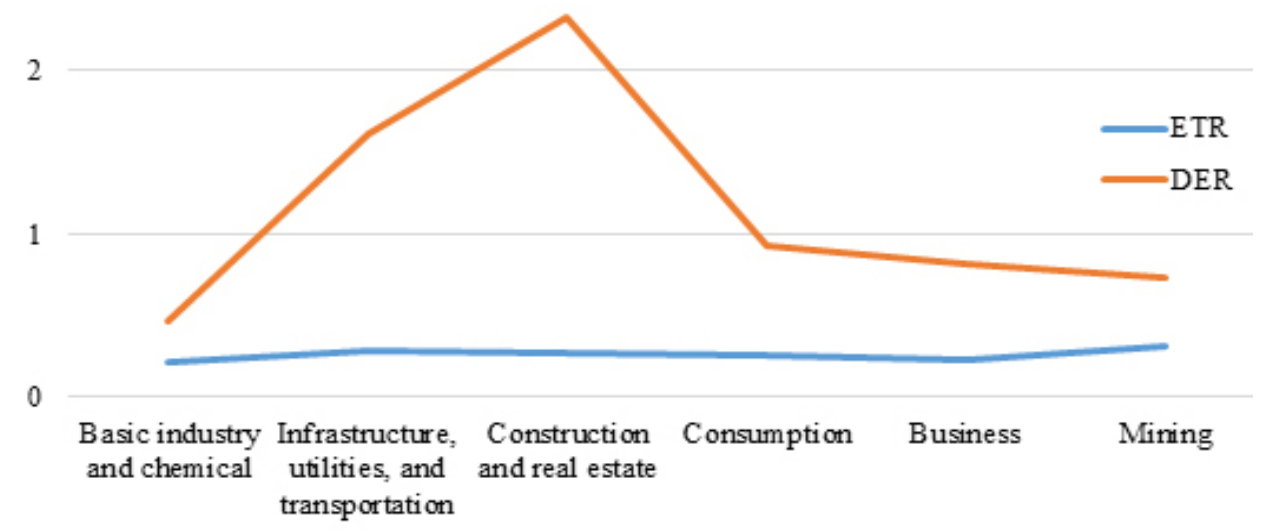

Figure 1. DER and ETR 2015-2019 based on sectors (IDX Financial Statement 2015-2019) 
The results of testing the classic assumptions on the whole model are free from classical assumption problem, then for further analysis the regression model can already be used. Normality test results on all models show the Jarque Bera probability value is less than 0.05 (Appendix) which means the data are not normally distributed, but in The Central Limit Theorem theory if the data size in the study $>30$ then the distribution of data in the study is considered to be normally distributed. Multicollinearity test results between the independent variables in the model are not conducted because there is only one independent variable in the model. Heteroscedasticity test results in all regression models indicate the absence of heteroscedasticity because the value of the absolute residuals of each variable is greater than 0.05 . The autocorrelation test results show that the overall Durbin Watson value of the model idicates an autocorrelation so that the handling of autocorrelation is necessary, namely the addition of Yt-1 which then produces the Durbin Watson value to 1.75 therefore no autocol in the model.

Based on the Table 6, the coefficient of determination (R2) measures the proportion of diversity Y (dependent variable) that can be explained by $\mathrm{X}$ (independent variable) in the model. Based on the results of the model obtained an R-Squared value of 93.46 percent, meaning that 93.46 percent of the variance of firm value can be explained by the variance of tax avoidance variables and the firm value in the previous period used while the remaining 6.54 percent is explained by other factors outside the model. The results of prob (F-statistic) of 0.0000 whose value is smaller than alpha of 5 percent; the conclusion is that there is a joint effect on the firm value or at least there is one of the independent variables that affect the firm value.

Regression results show the coefficient of tax avoidance is 0.247 with a probability of 0.0007 . This shows that ETR has a positive effect on firm value. If related to tax avoidance which is inversely related to ETR, it is concluded that tax avoidance is negatively related to firm value. When tax avoidance increases, the firm value will decrease. Meanwhile, the influence between tax avoidance and firm value produces probability values below critical value (0.05) so that tax avoidance has a significant effect on firm value in non-financial SOEs registered in LQ45.
SOE is a company whose ownership is dominated by the government so that every policy made looks at the perspective of the government at large. Regression results that show a significant negative relationship between tax avoidance and the firm value of SOE are very different from previous studies which generally produce a significant positive relationship (Khaoula et al. 2013; Chen et al. 2010; Wilson, 2009). The results of this study are consistent with the study of Wu (2009) which examines state ownership and good tax handling of corporate tax obligations. As a result, corporate tax obligations increase with the proportion of ownership by the government. Generally, companies that do tax avoidance will generate greater profits so that the firm value will increase. However, there are differences in companies controlled by the government, companies that do small tax avoidance that will increase the firm value. This is because SOEs are more transparent in providing financial reports and also the government's interest in taxation also encourages companies to report taxes properly. In addition, SOEs also have another objective, namely as a provider of community services so that it indirectly reinforces the obligation to pay taxes properly to help develop the country's economy to improve the welfare of society.

In the regression for private companies this study uses the Chow Test and Hausman Test to find out the right model to use. The results of the two tests show the right model used in this regression is the fixed effect model (FEM). To find out that the results of the regression model are free from classical assumption problems such as heteroscedasticity, multicollinearity, and autocorrelation, then the classical assumption test carried out on the FEM regression model that has been selected.

The results of testing the classic assumptions on the whole model is free from classical assumption problems, then for further analysis the regression model can already be used. Normality test results on all models show Jarque Bera probability values of less than 0.05 which means the data are not normally distributed, but in The Central Limit Theorem theory if the size of the data in the study $>30$ then the distribution of data in the study is considered to be normally distributed. Multicollinearity test results between the independent variables in the model are not done because there is only one independent variable in the model. 
Heteroscedasticity test results in all regression models indicate the absence of heteroscedasticity because the value of the absolute residuals of each variable is greater than 0.05 . The autocorrelation test results indicate that the Durbin Watson value of the whole model shows that there is an autocorrelation so that the handling of autocorrelation is necessary, namely the addition of Yt-1 which then produces the Durbin Watson value to 1.72 and there is no autocol in the model.

Based on Table 7 the coefficient of determination (R2) measures the proportion of variance $\mathrm{Y}$ (dependent variable) that can be explained by $X$ (independent variable) in the model. Based on the results of the model obtained an R-Squared value of 99.08 percent, meaning that 99.08 percent of the variance of firm value can be explained by the variance of tax avoidance variables and the firm value in the previous period used while the remaining 0.92 percent is explained by other factors outside the model. The results of prob (F-statistic) of 0.0000 whose value is smaller than alpha of 5 percent; the conclusion is that there is a joint effect on the firm value or at least there is one of the independent variables that affect the firm value.

Regression results show the coefficient of tax avoidance of -0.555 with a probability of 0.419 (Table 8 ). This shows that ETR has a negative effect on firm value. If related to tax avoidance which is inversely related to ETR, it is concluded that tax avoidance is positively related to firm value. When tax avoidance increases, the firm value will also increase. Meanwhile, the influence between tax avoidance and firm value results in probability values above critical value $(0.05)$ hence tax avoidance does not significantly influence the firm value in non-financial private companies listed in LQ45.

Table 6. The results of the regression of the impact of tax avoidance on SOE company value

\begin{tabular}{lccccc}
\hline & Variable & Coefficient & Std. Error & t-Statistic & Prob. \\
\hline Constant & C & 0.060 & 0.004 & 1.375 & 0.171 \\
Tax avoidance & ETR & 0.247 & 0.072 & 3.443 & 0.001 \\
The previousperiod firm value & TOBIN_S_Q(-1) & 0.896 & 0.027 & 33.545 & 0.000 \\
\hline R-squared & 0.934577 & & & \\
F-statistic & 254.2765 & & & & \\
Prob (F-statistic) & 0.0000 & & & & \\
\hline
\end{tabular}

Table 7. Results of regression of the impact of tax avoidance on the value of private companies

\begin{tabular}{lccccc}
\hline & Variable & Coefficient & Std. Error & t-Statistic & Prob. \\
\hline Constant & C & 0.965 & 0.203 & 4.758 & 0.000 \\
Tax avoidance & ETR & -0.555 & 0.686 & -0.809 & 0.419 \\
Firm value previous period & TOBIN_S_Q(-1) & 0.743 & 0.037 & 20.151 & 0.000 \\
\hline R-squared & 0.990794 & & & & \\
F-statistic & 2004.457 & & & & \\
Prob (F-statistic) & 0.0000 & & & & \\
\hline
\end{tabular}

Table 8 . Results of regression of the impact of tax avoidance on firm value based on company ownership

\begin{tabular}{lccc}
\hline & Company & \multicolumn{3}{c}{ ETR } & Definition \\
\cline { 2 - 4 } & Coefficient & Prob. & Positive significant \\
SOE & 0.246763 & 0.0007 & Negative not significant \\
\hline
\end{tabular}


A private company is a company whose primary ownership comes from domestic and foreign private parties. This company generally has a goal to get maximum profit for the benefit of the owner and management. The results of the analysis of research for private companies that there is no impact of tax avoidance activities on the firm value, which means that any activity to reduce corporate tax payments from private companies will not interfere with the firm value. The reason for this lack of impact is that investors generally do not really look at the activities of private company tax payments, but rather give priority to profits from the company and also dividends that will be given by the company. This condition also provides evidence that the need for additional tax payment rules is needed to keep companies in order to keep paying taxes properly.

\section{Managerial Implications}

This study recommends that company management conduct tax planning by taking into account the movement of profitability and firm size of SOEs. Increased company profits can be achieved by increasing productivity through business research and development activities as well as additional investment through shares on other companies. Companies are also advised to increase business size through increasing company assets and expanding business networks. While the recommendation for the government is to examine deeper the tax avoidance conducted by large companies in Indonesia in order to reduce the level of fraud in the taxation field and carry out fundamental reforms both in terms of regulations, institutions, and enhancing the capacity of human resources.

Investors with fundamental analysis type will analyze through the condition of the shares prospect, but from the results of this study it is expected that this type of investor does not determine the condition of the prospect of shares sectorally. There needs to determine through its ownership of state enterprises or private businesses. Investors who have the goal of investing in state-owned companies need to see how the the company's stance on tax avoidance because it is one of the effects of a decline in the firm value. In addition, investors who determine the prospect of shares through profitability and asset value need to conduct a deeper study of the tax avoidance of the selected company.

\section{CONCLUSIONS AND RECOMMENDATIONS}

\section{Conclusions}

Companies that are more dominant in doing tax avoidance are private companies compared to SOEs, because SOEs are generally more directly supervised so that they are more transparent in their decision making. Based on the results of the analysis obtained determinants that have a significant positive influence on state-owned companies on tax avoidance namely ROA and firm size, while in private companies there is no significant effect of the variables studied. The results of the analysis on the impact of tax avoidance on the value of private companies have no significant effect. While in SOEs, there is a significant negative effect of tax avoidance on firm value.

\section{Recommendations}

Factors that influence tax avoidance included in research are internal company information, therefore it is recommended that further research include the company's external variables (example: government policy and economic growth) to have implications for other parties. Capital intensity in research uses the approach to fixed assets, because large companies that are generally used fixed assets that have expired, so the size of the fixed assets has no effect on the ETR. Future studies are suggested measuring capital intensity using other methods such as the inventory approach. Also, there is a need to deepen research on the causes of companies doing tax avoidance and the strategies carried out in some companies that are seen doing too large tax avoidance

\section{REFERENCES}

Andreas, Enny S. 2017. Determinants of effective tax rate of the top 45 largest listed companies of Indonesia. International Journal of Management Excellence 9 (3): 1183-1188.

Appolos NN, Jerry K, Ogundajo, Grace O. 2016. Tax planning and firm value: empirical evidence from Nigerian consumer goods industrial sector. Research Journal of Finance and Accounting 7(12): 172-183.

Apsari L, Setiawan PE. 2018. Pengaruh tax avoidance terhadap nilai perusahaan dengan kebijakan dividen sebagai variabel moderasi [The effect of 
tax avoidance on firm value with dividend policy as a moderating variable]. E-Jurnal Akuntansi Universitas Udayana 23 (3): 1765-1790.

Atwood TJ, Drake MS, Myers LA. 2012. Home country tax system characteristics and corporate tax avoidance: international evidence. The Accounting Review 87(6): 1831-1860.

Budiman J. 2012. Pengaruh karakter eksekutif terhadap penghindaran pajak (tax avoidance) [Effect of executive character on tax avoidance]. [tesis]. Yogyakarta: Universitas Gadjah Mada.

Chen CK. 2013. Research on impacts of team leadership on team effectiveness. The Journal of American Academy of Business 5(1): 266-278

Chen, Shuping, Xia Chen \& Qiang Cheng. 2010. Are Family Firms more Tax Aggressiv than Nonfamily Firms? Journal of Financial Economics 95: 41-61.

Deak, D. 2009. Legal considerations of tax evasion and tax avoidance. Society and Economy 26 (1): 4185.

Desai MA, Dharmala D. 2009. Corporate tax avoidance and firm value. The Review of Economics and Statistics 91(3):537-546.

[DGT] Directorate General of Taxation. 2018. Laporan Kinerja DJP. Jakarta: Direktorat Jenderal Pajak.

Dyreng SD, Hanlon M, Maydew EL. 2010. The Effects of Executives on Corporate Tax Avoidance. The Accounting Review 85(4): 1163-1189.

Evangelos C. 2018. Tax avoidance and corporate governance attributes: evidence from listed companies in Greece. Corporate Ownership and Control 16(4): 77-86

Frank et al. 2009. Tax Reporting aggresiveness and its relation to aggressive financial reporting. Journal of Accounting Review 84 (2): 467- 496

Hanlon M, Heitzman S. 2010. A review of tax research. Journal of accounting and economics 50 : 127178

Hutama. 2007. Pengaruh pengetahuan informasi penggelapan pajak dan prinsip moral pada kecenderungan penghindaran pajak [Effect of tax evasion information knowledge and moral principles on tax avoidance tendencies] [tesis]. Yogyakarta: Universitas Gadjah Mada.

Imelia S. 2015. Analisis faktor yang mempengaruhi manajemen pajak dengan indikator tarif pajak efektif (ETR) pada perusahaan LQ45 yang terdaftar dalam Bursa Efek Indonesia tahun 2010-2012 [Analysis of factors affecting tax management with an effective tax rate (ETR) on
LQ45 companies listed on IDX in 2010-2012. Jurnal Online Mahasiswa (JOM) 2(1): 1-15.

Indonesia Stock Exchange. 2019. Financial statements. www.idx.co.id. [Sept 2019].

Irianto BS, Sudibyo YA, Wafirli A. 2017. The influence of profitability, leverage, firm size and capital intensity towards tax avoidance. International Journal of Accounting and Taxation 5(2) : 3341

Khaoula AF, Ahmed A. 2013. Tax planning and firm value: evidence from European companies. International Journal of Economics and Strategic Management Business 4(1): 73-78.

Kurniasih T, \& Sari MM. 2013. Pengaruh Profitabilitass, Leverage, Corporate Governance, Ukuran Perusahaan, dan Kompensasi Rugi Fiskal pada Tax Avoidance [Effects of Profitability, Leverage, Corporate Governance, Company Size, and Fiscal Loss Compensation on Tax Avoidance\}. Buletin Studi Ekonomi 18: 58 - 66.

Lestari N, Wardani R, Anggraita V. 2014. Pengaruh perencanaan pajak terhadap nilai perusahaan dengan moderasi corporate governance. [The effect of tax planning on firm value by corporate governance moderation]. Jurnal Akuntansi 12(2): 126-145.

Maharani IG, Suardana KA. 2014. Pengaruh corporate governance, profitabilitas, dan karakteristik eksekutif pada tax avoidance perusahaan manufaktur [The effect of corporate governance, profitability, and executive characteristics on manufacturing company tax avoidance]. E-Jurnal Akuntansi Universitas Udayana 9(2): 525-539.

Ministry of Finance Indonesia. 2017. Advertorial Nota Keuangan dan RAPBN 2017 [Advertorial Financial Note and State Budget 2017]. Jakarta: Kemenkeu RI.

Ministry of Finance Indonesia. 2019. Informasi $A P B N$ 2019 [APBN Information 2019]. Jakarta: Kemenkeu RI.

Nguyen THH, Phan GQ. 2017. The relationship between state ownership and tax avoidance level: empirical evidence from Vietnamese firms. Journal of Asian Business Strategy 7(1):1-12.

Richardson G, Lanis R. 2007. Determinants of the variability in corporate effective tax rates and tax reform: Evidence from Australia. Journal of Accounting and Public Policy 26:689-704.

Riyadi A. 2018. Pengaruh struktur kepemilikan pemerintah terhadap penghindaran pajak: studi 
pada perusahaan yang terdaftar di Bursa Efek Indonesia [Effect of government ownership structure on tax avoidance: a study of companies listed on the Indonesia Stock Exchange] [tesis]. Yogyakarta: Universitas Gadjah Mada.

Rodiguez EF, Arias AM. 2012. Do business characteristics determine an effective tax rate. Chinese Economy 45(6): 60-83.

Rosaria A. 2017. Who needs ethics? The impact of corporate social responsibility on tax aggressiveness [tesis]. Bandung: Institut Teknologi Bandung.

Rumiyati. 2016. Koneksi politik, manajemen laba, kualitas, audit, dan penghindaran pajak di Indonesia [Political connections, earnings management, quality, auditing and tax avoidance in Indonesia] [tesis]. Yogyakarta: Universitas Gadjah Mada.
Salvatore D. 2012. Managerial Economics: Principles and Worldwide Applications 7th Edition. Washington: Oxford University Press.

Sukamulja S. 2004. Good corporate governance di sektor keuangan: dampak good corporate governance terhadap kinerja perusahaan [Good corporate governance in the financial sector: the impact of good corporate governance on company performance]. Benefit 8(1): 1 - 25.

Vidiyanna R, Putra BI. 2017. Pengaruh Leverage, Profitability, Ukuran Perusahaan dan Proporsi Kepemilikan Institusional Terhadap Tax Avoidance [The effect of leverage, profitability, company size, and proportion of institutional ownership on tax avoidance]. Jurnal Ekonomi Manajemen Sumber Daya 19(1): 228-241.

Wilson RJ. 2009. An examination of corporate tax shelter participants. The Accounting Review 84(3):969-999. 